\title{
Advances in Maraging Steels for Additive Manufacturing
}

\author{
Christoph Turk, Horst Zunko, Christin Aumayr, Harald Leitner, and Marianne Kapp \\ voestalpine BÖHLER Edelstahl GmbH \& Co KG, Kapfenberg, Austria \\ Received December 13, 2018; accepted January 31, 2019; published online February 18, 2019
}

\begin{abstract}
Maraging steels such as 1.2709 are high strength high toughness alloys that gain their exceptional mechanical properties by the combination of nanometer-sized intermetallic precipitates and a martensitic matrix. Here the martensitic microstructure is not achieved by a high carbon content but by adding nickel to the chemical composition. In turn, the lack of carbon leads to good weldability and therefore makes these materials preferred candidates for additive manufacturing techniques, such as selective laser melting (SLM). Applications for SLM produced components are found especially in the tooling industry, where the implementation of inserts with intelligent conformal cooling channels in dies and moulds has already shown to drastically increase the tool lifetime. In this study, different maraging steels are investigated with respect to typical powder characteristics, such as sphericity, particle size distribution, on the one hand, and the microstructure as well as the achieved mechanical properties of the respective SLM printed parts, on the other hand.
\end{abstract}

Keywords: Maraging steel, Laser powder bed fusion L-PBF, Laser beam melting LBM, Precipitation hardening, Corrosion resistance

Weiterentwicklung von Maraging-Stählen für Additive Fertigung

Zusammenfassung: Maraging-Stähle wie 1.2709 sind Legierungen mit hoher Festigkeit und hoher Zähigkeit, die ihre außergewöhnlichen mechanischen Eigenschaften durch die Kombination von nanometergroßen intermetallischen Ausscheidungen und einer martensitischen Matrix erhalten. Die martensitische Mikrostruktur wird dabei nicht durch einen hohen Kohlenstoffgehalt erreicht, sondern durch Zugabe von Nickel zur chemischen Zusammensetzung. Das Fehlen von Kohlenstoff führt wiederum zu einer guten Schweißbarkeit und macht dadurch diese Materialien zu

H. Zunko $(\square)$

voestalpine BÖHLER Edelstahl GmbH \& Co KG,

Mariazeller Straße 25,

8605 Kapfenberg, Austria

horst.zunko@bohler-edelstahl.at bevorzugten Werkstoffen für additive Fertigungstechniken, wie beispielsweise das selektive Laserschmelzen (SLM). Anwendungen für derart hergestellte Komponenten finden sich vor allem in der Werkzeugindustrie für Spritzguss und Druckguss, wo der Einsatz von Formwerkzeugen mit intelligenten konturnahen Kühlkanälen bereits gezeigt hat, dass sich die Werkzeuglebensdauer drastisch erhöhen kann. In dieser Studie werden verschiedene Maraging-Stähle in Hinblick auf typische Pulvercharakteristika, wie Sphärizität, Partikelgrößenverteilung und Mikrostruktur sowie auf die erzielten mechanischen Eigenschaften der jeweiligen SLMDruckteile untersucht.

Schlüsselwörter: Maraging-Stahl, Laser

Pulverbettverfahren, L-PBF, Selektives Laser Schmelzen, Ausscheidungshärtung, Korrosionsbeständigkeit, Additive Fertigung

\section{Introduction}

The additive manufacturing ( $A M)$ technology is currently one of the fastest developing and growing technologies. This can be attributed to the fact that AM offers designers, engineers, and material scientists a lot of new opportunities to fulfil the desired properties of products [1]. Especially, the possibility to produce three dimensional parts directly from a CAD-model and the lower number of process steps needed to reach the final product, compared to conventional processing, e.g. casting, forming, machining, and more, ensure that $A M$ is a very important manufacturing method for future industry applications [1,2].

Metal additive manufacturing became popular with the first works of Schleifenbaum et al. [3,4], which was the initiation for the many AM machine producers and engineers as well as material scientists to get in contact with this new technology. Nowadays numerous metallic powder materials and different $A M$ processes are available to produce AM-parts. A very prominent AM process is the laser powder bed fusion (L-PBF) respectively laser beam melting (LBM) technique, in which the metal powder is spread in thin layers and consequently molten by a high energy laser beam 
to form a dense microstructure [2]. However, the variety of different steel alloys which can be processed by LBM is limited due to the challenging processability caused by the crack sensitivity of these materials $[5,6]$.

It is state of the art that the weldability without preheating temperature of carbon alloyed steels is limited by the carbon equivalent of approximately $0.2 \mathrm{wt} . \%$. Therefore, mostly carbon-free steels have been processed by LBM by now [2]. The most frequently used material, besides the austenitic alloys AISI $316 \mathrm{~L}$ or AISI 304 , is the $18 \mathrm{wt} .-\% \mathrm{Ni}$ maraging steel X3NiCoMoTi18-9-5 (BÖHLER W722 AMPO [7], 1.2709, Maraging 300) which is hardened by nm-sized intermetallic precipitates [8]. The well balanced property relationship between hardness, strength, toughness, and ductility, apart from the easy LBM-processability, lead to the fact that this alloy is one of the most LBM-produced steel powders [2]. Nevertheless, the microstructure of X3NiCoMoTi18-9-5 exhibits no corrosion resistance, due to the lack of chromium to form a surface protecting passive layer [9]. If corrosion resistance is demanded for specific applications, AM designers and $A M$ engineersrs must change their material selection to austenitic or precipitation hardened corrosion resistant maraging steels such as X5CrNiCuNb17-4-4 (BÖHLER N700 AMPO [10], 1.4548, 17$4 \mathrm{PH})$. These steels, however, exhibit a lower strength and hardness compared to X3NiCoMoTi18-9-5 [11]. Recently the newly developed cobalt-free corrosion resistant maraging steel BÖHLER M789 AMPO was introduced to the AM powder market [12]. This alloy provides a well-balanced property relationship of hardness, strength, toughness, ductility, and corrosion resistance in order to combine the characteristics of $\mathrm{X} 3 \mathrm{NiCoMoTi18-9-5}$ and $\mathrm{X} 5 \mathrm{CrNiCuNb17-}$ 4-4.

As a consequence, the metallic powders, the AM-processability and the mechanical properties as well as technological aspects, e.g. corrosion resistance, of the three different maraging steels mentioned above are compared to each other and discussed in this contribution.

\section{Experimental}

For this AM comparison study, three different maraging steels have been characterized. The metallic powders were produced by argon gas atomization and classified to the particle size distribution of $15-45 \mu \mathrm{m}$ by sieving at voestalpine BÖHLER Edelstahl $\mathrm{GmbH}$ \& Co KG, Kapfenberg, Austria. The chemical compositions of the powders were determined by a wet-chemical analysis and are listed in Table 1.

In order to characterize the powder properties, the particle size distributions were determined in accordance with DIN ISO 13320 as well as the sphericity of the powders by using the CAMSIZER XT of RETSCH. The PBF-AM production of the tested samples was carried out at the voestalpine Additive Manufacturing Center $\mathrm{GmbH}$, Düsseldorf, Germany. All powders were laser melted without a powder-bed pre-heating system, hence no information of the real powder-bed temperature was available. All build jobs were carried out under a controlled protective argon gas atmosphere with a constant oxygen level below $0.3 \%$, in order to prevent oxidation of the steels during laser melting. The AM machines used and processing parameters are given in Table 2.

The parameters for the different alloys given in Table 2 have been chosen in order to reach a target density above 99.5\% and a thorough design-of-experiment (DOE)-study was carried out prior to this work. For the characterization of the microstructure and the mechanical properties of the maraging alloys, tensile samples with dimensions of $\varnothing 12 \times 85 \mathrm{~mm}^{2}$ and Charpy V-notch impact toughness samples with dimensions of $12 \times 12 \times 57 \mathrm{~mm}^{3}$ were built in horizontal platform direction. The properties of the steels were evaluated in the individual heat treated condition in accordance with the recommended heat treatments of the bar material, as provided in [13]. The austenitization was carried out in a vacuum furnace of the type Schmetz IU 54/1F $2 \mathrm{R}$ followed by a $\mathrm{N}_{2}$-gas quench operation, and the single aging heat treatment was carried out in a Nabertherm

TABLE 1

Chemical composition of the three different maraging steel powders determined in the as-atomized condition by wet-chemical analysis

\begin{tabular}{llllllllll}
\hline wt.- $\%$ & $\mathrm{Fe}$ & $\mathrm{C}$ & $\mathrm{Ni}$ & $\mathrm{Cr}$ & $\mathrm{Co}$ & $\mathrm{Mo}$ & $\mathrm{Ti}$ & $\mathrm{Al}$ & $\mathrm{Cu}$ \\
\hline W722 AMPO & $\mathrm{Bal}$ & $<0.03$ & 18.0 & - & 9.0 & 5.0 & 1.0 & - & - \\
\hline N700 AMPO & $\mathrm{Bal}$ & $<0.07$ & 4.0 & 17.0 & - & 0.3 & - & - & 3.3 \\
\hline M789 AMPO & $\mathrm{Bal}$ & $<0.02$ & 10.0 & 12.2 & - & 1.0 & 1.0 & 0.6 & - \\
\hline
\end{tabular}

\begin{tabular}{|llcccc}
\hline $\begin{array}{l}\text { TABLE 2 } \\
\text { AM-machines and processing parameters used in this study }\end{array}$ & Laser power $[\mathrm{W}]$ & $\begin{array}{l}\text { Scan speed } \\
{[\mathrm{mm} / \mathrm{s}]}\end{array}$ & $\begin{array}{l}\text { Scan line spacing } \\
{[\mu \mathrm{m}]}\end{array}$ \\
\hline Alloy & AM-machine & Slice thickness $[\mu \mathrm{m}]$ & 500 & 100 \\
\hline W722 AMPO & $\begin{array}{l}\text { TRUMPF TruPrint } \\
1000\end{array}$ & 20 & 120 & 600 & 160 \\
\hline N700 AMPO & $\begin{array}{l}\text { SLM Solutions } \\
\text { SLM280 }\end{array}$ & 30 & 250 & 763 & 87 \\
\hline M789 AMPO & $\begin{array}{l}\text { TRUMPF TruPrint } \\
1000\end{array}$ & 20 & 160 & 760 \\
\hline
\end{tabular}




\begin{tabular}{|c|c|c|}
\hline \multicolumn{3}{|c|}{$\begin{array}{l}\text { TABLE } 3 \\
\text { Heat treatment operations for the different alloys } \\
\text { based on the recommended heat treatments for the } \\
\text { bar material, as given in [13] }\end{array}$} \\
\hline Alloy & $\begin{array}{l}\text { Solution anneal- } \\
\text { ing }\end{array}$ & Aging treatment \\
\hline W722 AMPO & $\begin{array}{l}960^{\circ} \mathrm{C} \text { for } 5 \mathrm{~h} \text { fol- } \\
\text { lowed by } 820^{\circ} \mathrm{C} \\
\text { for } 2 \mathrm{~h} \text {, air cool }\end{array}$ & $490^{\circ} \mathrm{C}$ for $3 \mathrm{~h}$ \\
\hline N700 AMPO & $\begin{array}{l}1038^{\circ} \mathrm{C} \text { for } 30 \mathrm{~min}, \\
\text { air cool }\end{array}$ & $496^{\circ} \mathrm{C}$ for $4 \mathrm{~h}$ \\
\hline M789 AMPO & $\begin{array}{l}1000^{\circ} \mathrm{C} \text { for } 1 \mathrm{~h} \text {, air } \\
\mathrm{cool}\end{array}$ & $500^{\circ} \mathrm{C}$ for $3 \mathrm{~h}$ \\
\hline
\end{tabular}

N60/85 HA chamber furnace. The detailed heat treatments are given in Table 3.

After the completed heat treatments, the samples were machined to the final shape according to ASTM E8 and ASTM E23. The microstructure and internal porosity were determined by using the light optical microscope (LOM) Olympus BX53M. The HRc hardness testing was done by the EmcoTest M4R 02563 hardness testing machine, the impact toughness was evaluated by the Zwick Roell PSW
750 TZE HA impact tester, and the tensile tests were carried out on a Zwick Roell/Beta 200 and Beta 400 tensile testing machine. Corrosion resistance testings were carried out with the two maraging steels BÖHLER N700 AMPO and M789 AMPO. For that purpose eletrochemical tests at room temperature were carried out with heat treated samples. The specimens were grinded prior to testing. To let the passivation layer rebuild, the test was carried out $12 \mathrm{~h}$ after grinding the earliest. As electrolyte, synthetic sea water with addition of $\mathrm{HCl}$ at a $\mathrm{pH}$-level of 4 was used. The testing was done with a cyclic course of the applied potential. To represent the corrosion resistance, the value of the characteristic potential at $10^{-5} \mathrm{~A} / \mathrm{cm}^{2}$ was determined.

\section{Results and Discussion}

The particle size distributions of the three different AMPO powders are visualized in Fig. 1a, and the corresponding d10, d50, and d90 values are shown in Fig. $1 \mathrm{~b}$.

The results in Fig. $1 \mathrm{a}$ and $\mathrm{b}$ show that the sieved W722 AMPO and M789 AMPO exhibit finer powder particles compared to the N700 AMPO powder. All AMPO
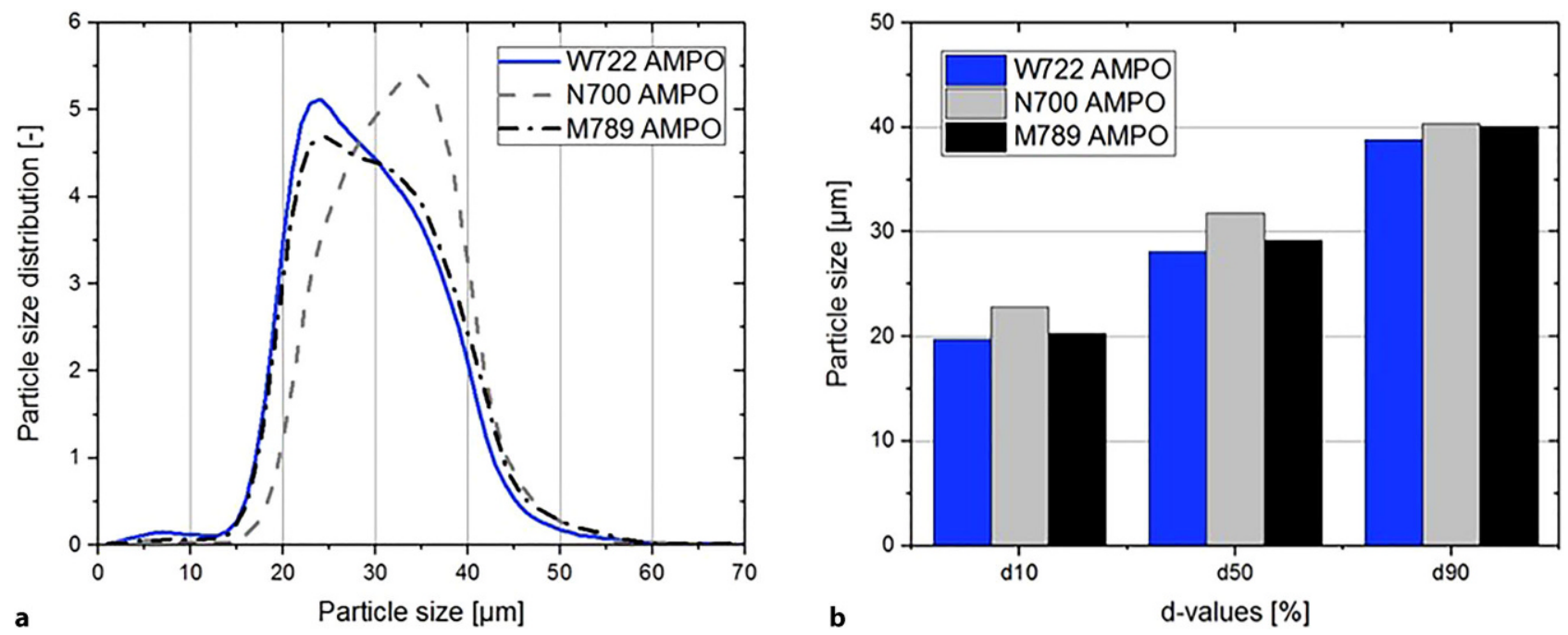

Fig. 1: a Particle size distributions of the different powders and $\mathbf{b}$ the corresponding d-values d10, d50, and d90

Fig. 2: a Sphericity values of the powders and b exemplary SEM-image of the M789 AMPO powder in SE-mode
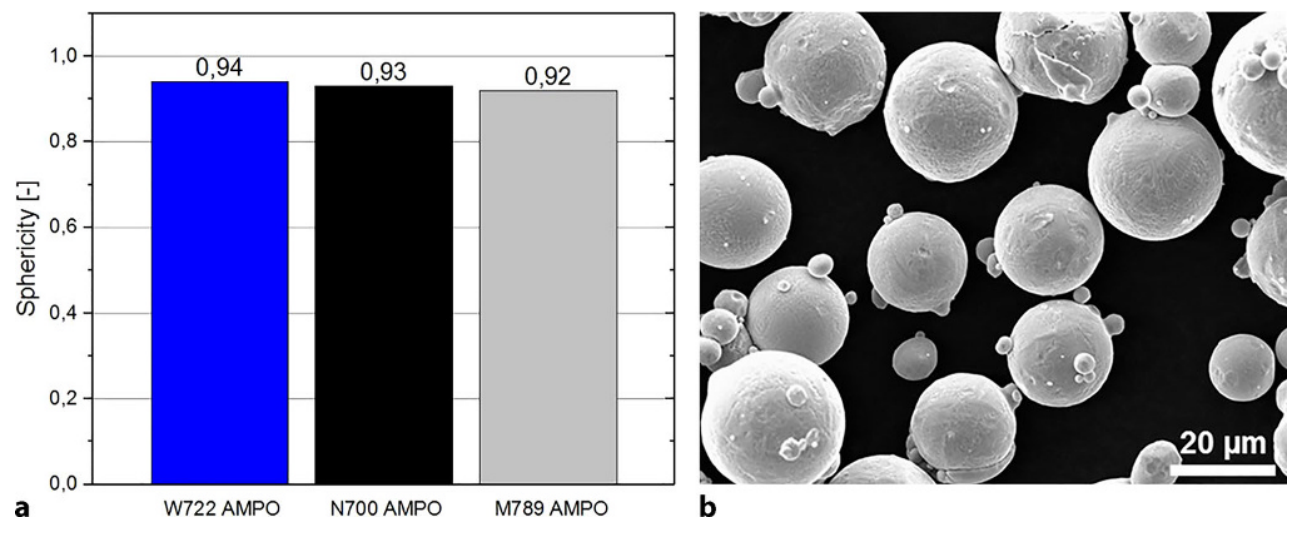


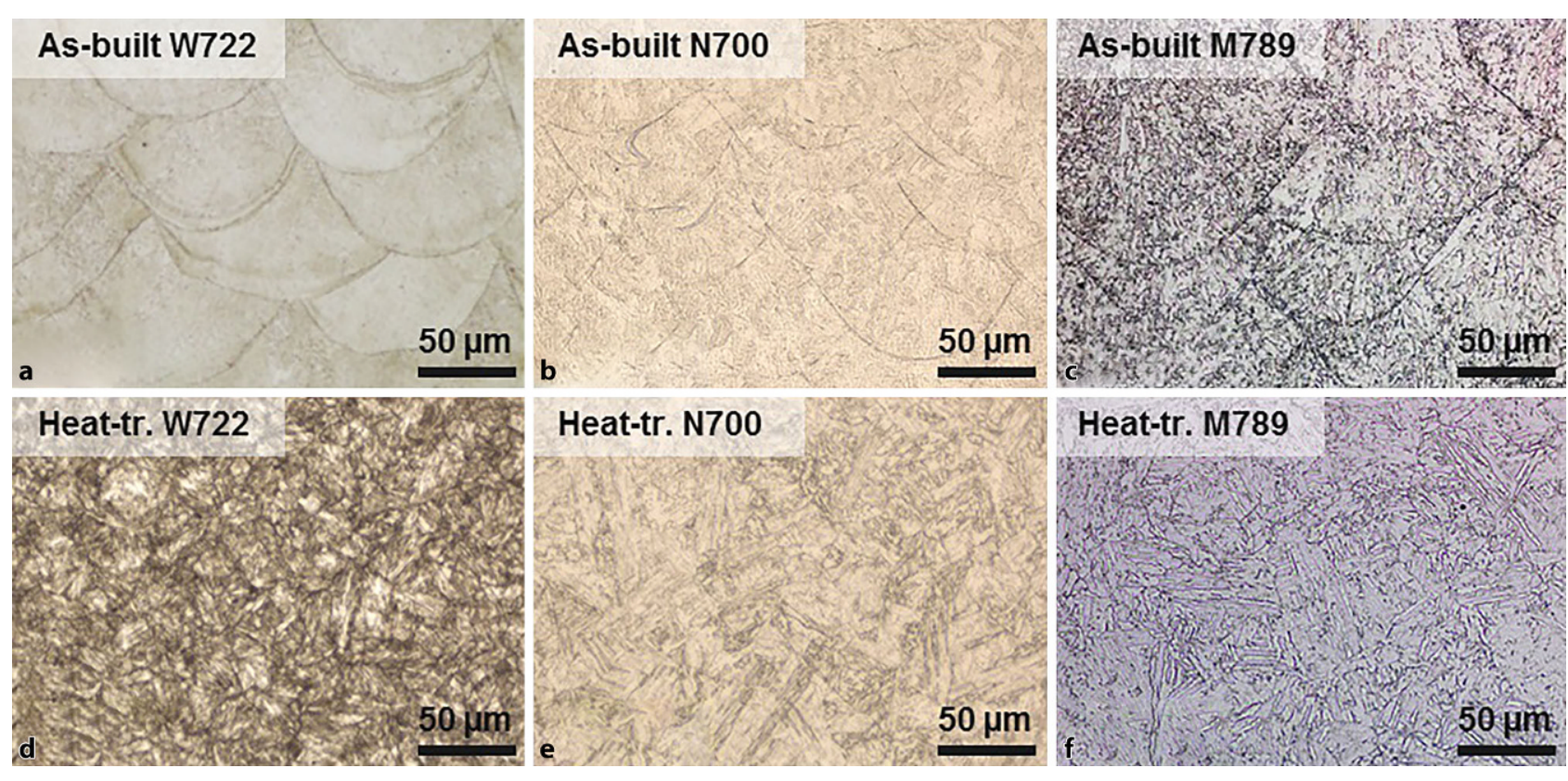

Fig. 3: LOM images of the as-built microstructure of a W722 AMPO (etched with $3 \% \mathrm{HNO}_{3}$ acid), b N700 AMPO (etched with V2A etchant), and $\mathbf{c}$ M789 AMPO (etched with V2A etchant). LOM images of the heat treated microstructure of $\mathbf{d}$ W722 AMPO (etched with $3 \% \mathrm{HNO}_{3}$ acid), e N700 AMPO (etched with V2A etchant), and $\mathbf{f M 7 8 9}$ AMPO (etched with V2A etchant)
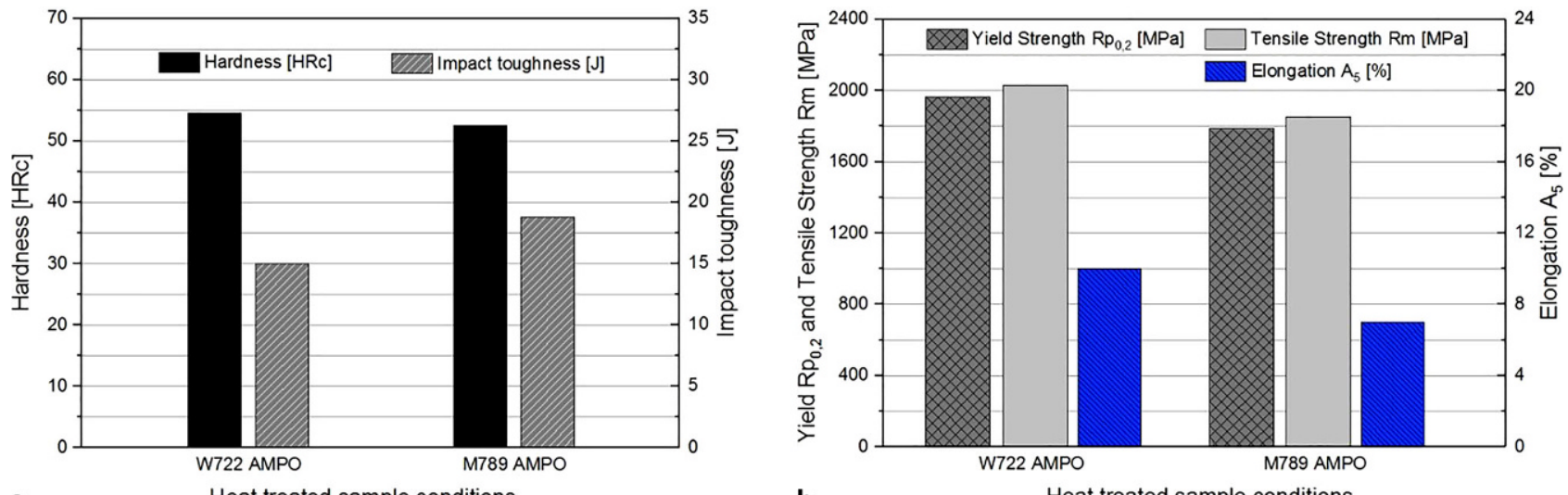

a

Heat treated sample conditions

b

Heat treated sample conditions

Fig. 4: a Comparison of hardness and toughness as well as b comparison of the tensile properties of the heat treated sample conditions of W722 AMPO and M789 AMPO

powders, however, are within the desired particle size fraction of 15 to $45 \mu \mathrm{m}$. The tight particle size distributions between $15-45 \mu \mathrm{m}$ are also well presented in the d10, d50, and $\mathrm{d} 90$ values in Fig. $1 \mathrm{~b}$. In addition to this, the powder morphology has been evaluated by the sphericity-value and qualitatively with SEM investigations in SE-mode. The results are shown in Fig. $2 a$ and $b$.

In Fig. 2a it can be seen that the different powders exhibit similar sphericity-values of at least 0.9 . Moreover, Fig. $2 b$ shows an exemplary SEM-image of the metallic powder particles of the maraging steel M789 AMPO. The powder morphology in Fig. $2 \mathrm{~b}$ confirms the high sphericity-values of the powder as presented in Fig. 2a. In addition to this, the SEM image reveals a low amount of satellites, which are bonded to the larger powder particles.

The printed samples have been characterized by LOM to evaluate the AM process in terms of homogenous weld- ing behavior and internal porosity. Fig. 3a-c illustrate the microstructure of the as-built conditions and Fig. $3 d-f$ the microstructure of the heat treated samples.

Fig. 3a-c indicate the typical microstructure of as-built sample conditions. Each welding operation can be clearly seen, and it is obvious that the binding behavior of the individual welded powder-layers is sufficient, since no cracks, binding defects, or internal porosity can be seen. These results represent the well-chosen AM process parameters to reach a density above $99.88 \%$ for W722 AMPO, 99.96\% for N700 AMPO, and $99.84 \%$ for M789 AMPO. If a hardening heat treatment is applied, however, the typical AM-welding microstructure disappears, as can be seen in Fig. $3 d-f$. In these conditions, the microstructure is martensitic and very homogeneous. This microstructure is typical for these steels and comparable to the microstructure of a heat treated bar material $[8,9]$. 


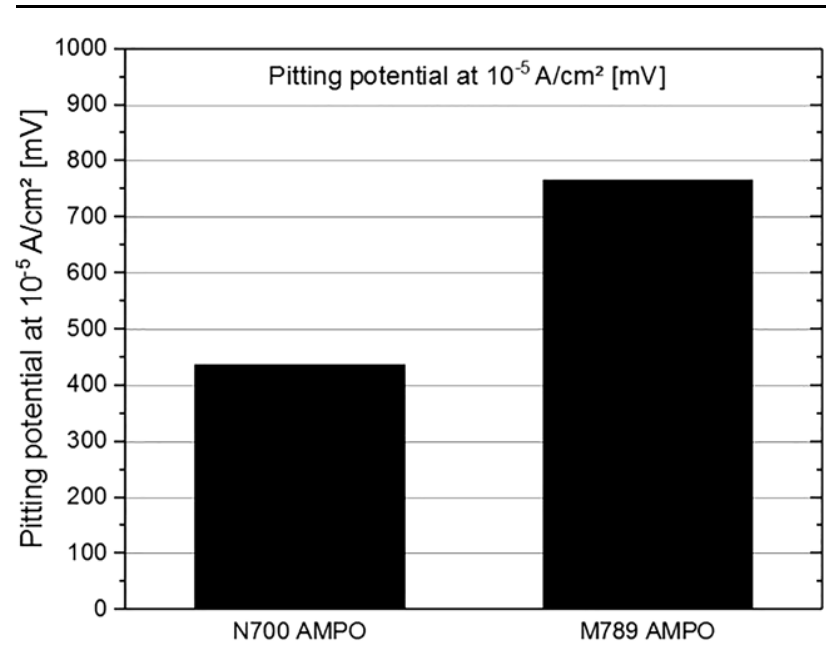

Heat treated sample conditions

Fig. 5: Comparison of the corrosion resistance of N700 AMPO and M789 AMPO in synthetic sea water

Furthermore, the mechanical properties of the individual heat treatment conditions of W722 AMPO and M789 AMPO are compared to each other. The results of the hardness, impact toughness, and tensile testing are illustrated in Fig. 4a and $b$.

In Fig. 4a it can be seen that the hardness value for M789 AMPO is in a comparable range to W722 AMPO above 52 HRc. In contrast to this, M789 AMPO exhibits a higher impact toughness above $17 \mathrm{~J}$ in comparison to W722 AMPO. The strength of M789 AMPO, shown in Fig. 4b, is slightly lower than W722 AMPt. Yet, from all these results it can be concluded that W722 AMPO and M789 AMPO exhibit similar mechanical properties in terms of high strength, ductility, and toughness, which are typical for $\mathrm{Fe}-\mathrm{Ni}(\mathrm{Co})$ martensitic maraging steels [13].

In addition to the mechanical properties, the corrosion resistance has been evaluated by electrochemical tests. Fig. 5 shows the pitting potential of M789 AMPO compared to N700 AMPO in synthetic sea water at room temperature.

M789 AMPO shows a substantially higher pitting potential than N700 AMPO. Since the PREN (PREN $=\% \mathrm{Cr}+$ $3.3 \% \mathrm{Mo}+16 \% N$ ) values of both alloys are in the same range, this result is unexpected. Influence factors on the pitting behavior, such as cleanliness and porosity, will be studied to gain further insight.

\section{Summary and Outlook}

This study gives a first insight into the properties of LBMmanufactured parts by using the AMPO maraging steel powders W722 AMPO, N700 AMPO, and M789 AMPO of voestalpine Böhler Edelstahl. The main results can be summarized as follows:

- All three different AMPO maraging steel powders, exhibit a tight particle size distribution. The sphericity is above $90 \%$ and the powder particles exhibit typical features (e.g.: low amount of satellites) of state-of-the-art gas atomized powders.

- In the as-built conditions, the microstructure show the typical layered structure. Yet, solution annealing and aging lead to a recrystallization and formation of the typical annealed $\mathrm{Fe}-\mathrm{Ni}(\mathrm{Co})$ martensitic-microstructure.

- All three AMPO maraging steels exhibit mechanical properties comparable to the conventional bar material in the heat treated condition.

- M789 AMPO is a promising candidate for applications which require the mechanical properties of W722 AMPO and the corrosion resistance of N700 AMPO and above.

Open Access This article is distributed under the terms of the Creative Commons Attribution 4.0 International License (http://creativecommons. org/licenses/by/4.0/), which permits unrestricted use, distribution, and reproduction in any medium, provided you give appropriate credit to the original author(s) and the source, provide a link to the Creative Commons license, and indicate if changes were made.

Publisher's Note. Springer Nature remains neutral with regard to jurisdictional claims in published maps and institutional affiliations.

\section{References}

1. Wohler, T.: Wohler Report 2014, 19th Ed. Wohler Assoc., Fort Collins, Colorado 80525 USA, ISBN 978-0-9913332-0-2, p. 227

2. Herzog, D.; Seyda, V.; Wycisk, E.; Emmelmann, C.: Additive manufacturing of metals, Acta Mater., 117 (2016), pp 371-392, https://doi. org/10.1016/j.actamat.2016.07.019

3. Schleifenbaum, H.; Diatlov, A.; Hinke, C.; Bültmann, J.; Voswinckel, $\mathrm{H}$.: Direct photonic production: towards high speed additive manufacturing of individualized goods, Prod. Eng., 5 (2011) pp 359-371, doi:10.1007/s11740-011-0331-0

4. Schleifenbaum, H.; Meiners, W.; Wissenbach, K.; Hinke, C.: Individualized production by means of high power Selective Laser Melting, CIRP J. Manuf. Sci. Technol., 2 (2010), pp 161-169, https://doi.org/ 10.1016/j.cirpj.2010.03.005

5. Giedenbacher, J.; Aziz, H.; Stefan, W.; Sommitsch, C.: Processing and Material Properties of Hot Work Tool Steels Manufactured by Selective Laser Melting, in Event Met. Addit. Manuf. Conf. 2016-Voestalpine Stahlwelt, Linz, Austria, Linz, 2016, p. 7.

6. Mertens, R.; Vrancken, B.; Holmstock, N.; Kinds, Y.; Kruth, J.-P. Humbeeck, J.: Influence of Powder Bed Preheating on Microstructure and Mechanical Properties of H13 Tool Steel SLM Parts, 2016, doi:10.1016/j.phpro.2016.08.092.

7. voestalpine BÖHLER Edelstahl GmbH \& Co KG, BÖHLER W722 AMPO Product Data Sheet, 2018

8. Baker, J.; Swann, P. R.: The Hardening Mechanism in Maraging Steels, Trans ASM, 57 (1954), pp 1008-1011

9. Scheidl, H.; Krainer, E.: Grundlagen und technische Besonderheiten von Maraging-Stählen, Sonderdruck aus "Radex-Rundschau., 4 (1977), pp 310-327

10. voestalpine BÖHLER Edelstahl GmbH \& Co KG, BÖHLER N700 AMPO Product Data Sheet, 2018

11. Sedlak, J.; Rican, D.; Piska, M.; Rozkosny, L.: Study of Materials Produced by Powder Metallurgy Using Classical and Modern Additive Laser Technology, 2015, doi:10.1016/j.proeng.2015.01.488

12. voestalpine BÖHLER Edelstahl $\mathrm{GmbH}$ \& Co KG, BÖHLER M789 AMPO Product Data Sheet, 2018

13. voestalpine BÖHLER Edelstahl GmbH \& Co KG, Böhler Edelstahl Handbuch, 2005. 